Tropical Journal of Pharmaceutical Research October 2019; 18 (10): 2089-2094

ISSN: 1596-5996 (print); 1596-9827 (electronic)

(1) Pharmacotherapy Group, Faculty of Pharmacy, University of Benin, Benin City, 300001 Nigeria.

Available online at http://www.tjpr.org

Original Research Article

http://dx.doi.org/10.4314/tjpr.v18i10.13

\title{
Yeast sludge and its components ameliorate ochratoxin A- induced toxicity in broiler chicks
}

\author{
Huma Mujahid $^{1 *}$, Abu Saeed Hashmi ${ }^{2}$, Muhammad Zargham Khan ${ }^{3}$, Muhammad \\ Tayyab $^{1}$, Wasim Shehzad ${ }^{1}$ \\ ${ }^{1}$ Institute of Biochemistry and Biotechnology, ${ }^{2}$ University of Veterinary and Animal Sciences, and Ripha College of Veterinary \\ Medicine, Lahore, ${ }^{3}$ Pathology Department, University of Agriculture, Faisalabad, Pakistan
}

${ }^{*}$ For correspondence: Email: huma.mujahid@uvas.edu.pk

\begin{abstract}
Purpose: To investigate the protective effect of yeast sludge (YS) and its components against ochratoxin A (OTA) in broiler chicks.

Methods: Ochratoxin A (OTA) was produced through solid state fermentation, and quantified using high performance liquid chromatography (HPLC). A total of 1250 one-day old broiler chicks of Arbreaker breed were randomly assigned to five diet groups $(A-E)$ replicated five times in such a way that each replicate had 50 chicks. The five diet groups were: $A$ (normal poultry feed), B (200 $\mu \mathrm{g} / \mathrm{kg}$ OTA), C (200 $\mu \mathrm{g} / \mathrm{kg}$ OTA plus $2 \mathrm{~g} / \mathrm{kg}$ YS), D (200 $\mu \mathrm{g} / \mathrm{kg}$ OTA plus $2 \mathrm{~g} / \mathrm{kg}$ yeast sludge cell mass, YSCM), and E (200 $\mu \mathrm{g} / \mathrm{kg}$ OTA plus $2 \mathrm{~g} / \mathrm{kg}$ yeast sludge cell wall (YSCW). The study lasted 35 days. Indices of liver and kidney functions were determined, as well as histopathological examination of samples of kidney, liver and bursa of Fabricius.

Results: Supplementation of chicks diet with OTA at a dose of $200 \mathrm{ppb}$ significantly reduced serum levels of total protein (TP), albumin, and creatinine, but significantly raised the activities of aspartate aminotransferase (AST) and alanine aminotransferase (ALT) $(p<0.05)$. However, inclusion of $Y S$, YSCM, and YSCW in OTA-contaminated diet significantly reversed the effect of OTA on the indices of liver and kidney functions ( $p<0.05)$. Yeast sludge and its components also significantly ameliorated OTA-induced histological changes in the liver, kidney and bursa of Fabricius.

Conclusion: These results indicate that $Y S$ and it components improve hepatorenal function and histological changes induced by OTA.
\end{abstract}

Keywords: Ochratoxin A, Yeast sludge, Aspergillus ochraceus, Liver function, Histology

\begin{abstract}
This is an Open Access article that uses a fund-ing model which does not charge readers or their institutions for access and distributed under the terms of the Creative Commons Attribution License (http://creativecommons.org/licenses/by/4.0) and the Budapest Open Access Initiative (http://www.budapestopenaccessinitiative.org/read), which permit unrestricted use, distribution, and reproduction in any medium, provided the original work is properly credited.
\end{abstract}

Tropical Journal of Pharmaceutical Research is indexed by Science Citation Index (SciSearch), Scopus, International Pharmaceutical Abstract, Chemical Abstracts, Embase, Index Copernicus, EBSCO, African Index Medicus, JournalSeek, Journal Citation Reports/Science Edition, Directory of Open Access Journals (DOAJ), African Journal Online, Bioline International, Open-J-Gate and Pharmacy Abstracts

\section{INTRODUCTION}

Ochratoxin A (OTA) is a nephrotoxic mycotoxin produced predominantly by Aspergillus ochraceus in tropical regions, and by Penicillium verrucosum, in temperate regions. It is a fungal secondary metabolite present in agricultural produce [1]. Humans come in contact with OTA through consumption of contaminated foods [2]. The toxicological effects of OTA are manifested in form of acute and chronic nephrotoxicity, which lead to kidney lesions [3]. Ochratoxin A 
(OTA) has also been linked to Balkan endemic nephropathy, a disease characterized by progressive kidney fibrosis which may lead to urinary tract tumours. OTA is considered as a possible human carcinogen (group 2B) [5].

Studies have shown that OTA is an occupational hazard [6]. Some of the methods used to detoxify OTA involve physical, chemical, physiochemical and microbiological processes [7]. An effective approach for detoxification of mycotoxins is the use of functional foods which contain valuable microorganisms that can efficiently bind mycotoxins in the gastrointestinal tract (GIT), thereby minimizing their toxic effects through reduction in the amount that is absorbed into the systemic circulation [8].

Yeast sludge (YS) refers to leftover yeast at the bottom of the bioreactor during the fermentation of sugars. It is also known as spent yeast or trub. It is a waste product in the distillery industry, and it is very hard to manage and dispose.

The three commonly used species of yeast in distillery industries are Saccharomyces cerevisiae, Candida guilliermondii and Candida parapsilosis [9]. Glucomannan, which is present in cell wall of yeast is usually added to food products to adsorb mycotoxins. It has become necessary to develop effective measures for reducing the level of OTA in feedstuffs because of its high level of toxicity. The present study investigated the protective effect of $\mathrm{YS}$ and its components in broiler chicks exposed to OTA.

\section{EXPERIMENTAL}

\section{Production and determination of OTA}

Identified toxigenic strain culture of Aspergillus ochraceus (CECT 2948) was purchased from Culture Collection Centre, University De Valencia, Spain. Solid state fermentation method of Zahoor et al was used for OTA production with slight modifications [10]. Wheat grains $(20 \mathrm{~g})$ soaked in $20 \mathrm{~mL}$ of distilled water was autoclaved at $121^{\circ} \mathrm{C}$ for $15 \mathrm{~min}$ at a pressure of $15 \mathrm{P} / \mathrm{In}^{2}$. Autoclaved distilled water $(20 \mathrm{~mL})$ was added, along with $1 \mathrm{~mL}$ of inoculum. The flask was shaken once daily to avoid clumping. It was then placed in an incubator at $28{ }^{\circ} \mathrm{C}$ in the dark for 21 days. Ochratoxin A (OTA) was thereafter isolated using the method of Bayman et al [11]. A $100-\mathrm{mL}$ mixture of acetonitrile: water $(86: 14, \mathrm{v} / \mathrm{v})$ was added to the flask and placed on an orbital shaker for $35 \mathrm{~min}$ at $100 \mathrm{rpm}$. The resultant solution was filtered, and the filtrate was concentrated by evaporation on a water bath at $60{ }^{\circ} \mathrm{C}$. The concentrate was reconstituted in 1
$\mathrm{mL}$ of methanol. The purified extract was quantified using HPLC (Agilent 1100 system) with a purifying column of mycosep 229 ochre, and mobile phase of acetonitrile: water: acetic acid (99:99:2).

\section{Isolation of YSCM and YSCW}

Yeast sludge (YS) was obtained from Shukkar Ganj Sugar Mill, Jhang, Pakistan. It was transferred to a sterilized container, mixed thoroughly with sterilized distilled water, and refrigerated for stratification to occur. The top and bottom layers were discarded, while the middle layer was washed with phosphoric acid, $\mathrm{pH} 2$ to kill bacteria. It was then centrifuged at $5000 \mathrm{rpm}$ for $10 \mathrm{~min}$ to obtain a residue which was subsequently oven-dried at $71{ }^{\circ} \mathrm{C}$. Sonication of YSCM was performed using a homogenizer operated at $40 \mathrm{kHz}$. Disruption of YS was carried out at $4{ }^{\circ} \mathrm{C}$, and consisted of four cycles of sonication for 5 min and 2 min break. The resultant mixture was centrifuged at $1,500 \mathrm{~g}$ for $10 \mathrm{~min}$ to separate the cell walls of YSCs [12].

\section{Animal studies}

Animal studies were conducted after approval by the Animal Ethics Committee, University of Veterinary and Animal Sciences, Lahore (approval no. Dr/268). The procedures used for the study were based on the guidelines of National Research Council Committee [13]. A total of 1250 1-day old broiler chicks of Arbreaker breed were randomly assigned to five diet groups (A - E) replicated five times in such a way that each replicate had 50 chicks. the basal ration of chicks was assayed for the presence of OTA and other mycotoxins before the start of the study. The five diets formulated were: A (normal poultry feed), B $(200 \mu \mathrm{g} / \mathrm{kg}$ OTA $), C(200 \mu \mathrm{g} / \mathrm{kg}$ OTA plus $2 \mathrm{~g} / \mathrm{kg}$ YS), D (200 $\mu \mathrm{g} / \mathrm{kg}$ OTA plus $2 \mathrm{~g} / \mathrm{kg}$ YSCM), and E $(200 \mu \mathrm{g} / \mathrm{kg}$ OTA plus $2 \mathrm{~g} / \mathrm{kg}$ YSCW). The study lasted for 35 days, and was conducted using completely randomized design (CRD).

\section{Biochemical analysis}

Blood (2 mL) was collected from the brachial vein of chicks. The blood was centrifuged at $3000 \mathrm{rpm}$ to obtain serum which was refrigerated at $-20^{\circ} \mathrm{C}$. Serum levels of TP, albumin, and creatinine, and activities of ALT and AST were determined using their respective kits.

\section{Histological examination}

At the end of 35 days, the chicks were euthanized, and the kidney, liver and bursa of 
Fabricius were excised and subjected to histopathological examination. The organs were fixed in $10 \%$ neutral-buffered formalin for $72 \mathrm{~h}$.

The specimens were then treated with graded series of alcohol and washed with three changes of xylene before being embedded in paraffin. Serial sections (each 3 - $5 \mu \mathrm{m}$ thick) were sliced and stained with hematoxylin and eosin (H \& E) according to standard method and observed under light microscope using an image analyser (Image Proplus 3.0) [14].

\section{Statistical analysis}

Data are expressed as mean \pm SEM. Statistical analysis was performed using SPSS (version 20.0). Groups were compared using Student $t$ test. Values of $p<0.05$ were considered statistically significant.

\section{RESULTS}

\section{Effect of OTA on liver and kidney functions}

Supplementation of the diet of chicks diet with OTA at $200 \mathrm{ppb}$ significantly reduced serum levels of TP, albumin and creatinine, but significantly elevated the activities of ALT and AST $(p<0.05)$. However, the inclusion of YS, YSCM and YSCW in OTA-contaminated diet significantly reversed the effect of OTA on these biochemical parameters $(p<0.05$; Table 1$)$.

\section{Effect of OTA on histology of the kidney}

The results of histological examination showed that the kidneys of chicks in control group exhibited normal renal architecture and did not show any significant histopathological changes. On the other hand, kidney sections of chicks fed diet contaminated with 200 ppb OTA (group B) were characterized by histological changes such as cytoplasmic swelling, degeneration of epithelial cells of proximal convoluted tubules (PCT), mononuclear leucocytes infiltration, and focal renal hemorrhage. However, histological examination of kidneys of chicks in group C (group fed OTA contaminated diet supplemented with $Y S$ ) revealed significant improvement in OTA-induced histological changes, but with a few cellular degeneration in some areas. Histological examination of kidneys of chicks in groups $D$ and $E$ revealed marked improvement in proximal convoluted tubules that were damaged by OTA. These results are shown in Figure 1.

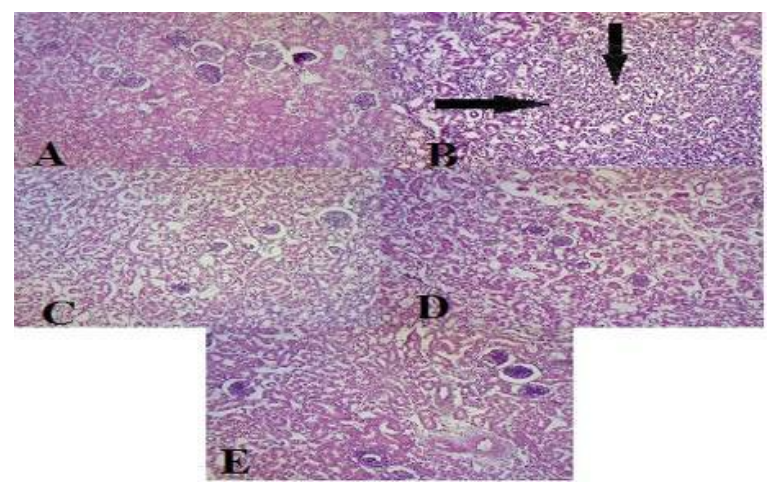

Figure 1: Histological features of kidneys of chicks $(\mathrm{H}$ $\& E, \times 100)$. A: Kidney of control chicks showing normal glomerulus and tubules; B: Kidney section of chicks fed OTA contaminated diet showing necrotic changes with indistinguishable glomerulus and renal tubules (thick arrows); C: Kidney of OTA and YSexposed chicks showing recovery of parenchyma of kidney; D: Kidney section of chicks given OTAcontaminated diet supplemented with YSCM, showing recovery of parenchyma of kidney; and E: Kidney section of chicks fed OTA-contaminated diet supplemented with YSCW, showing normal renal architecture

\section{Effect of OTA on histology of the liver}

Liver section of control group chicks revealed normal architecture. However, liver sections of chicks fed OTA-contaminated diet (Group B) showed adverse histological changes such as necrosis of epithelial cell lining the bile duct, thickened epithelial walls, hepatic haemorrhage, aggregation of focal mononuclear cells and portal infiltration of neutrophils. However, liver sections from chicks in group $\mathrm{C}$ showed significant improvements in histological changes induced by OTA.

Table 1: Effect of OTA, YS, YSCM and YSCW supplementations on levels and activities of selected biochemical parameters in the chicks

\begin{tabular}{|c|c|c|c|c|c|}
\hline Group & $\mathrm{TP}(\mathrm{g} / \mathrm{dL})$ & $\begin{array}{l}\text { Albumin } \\
\text { (g/dL) }\end{array}$ & $\begin{array}{c}\text { ALT } \\
\text { (IU/dL) }\end{array}$ & $\begin{array}{c}\text { AST } \\
\text { (IU/dL) }\end{array}$ & $\begin{array}{c}\text { Creatinine } \\
\text { (g/dL) }\end{array}$ \\
\hline $\begin{array}{l}\text { A (normal Feed) } \\
\text { B (normal feed + OTA) } \\
C \text { (normal feed + OTA+ yeast sludge) } \\
\text { D (normal feed + OTA+ YSCM) } \\
\text { E (normal feed + OTA+YSCW })\end{array}$ & $\begin{array}{l}3.02 \pm 0.19 \\
2.88 \pm 0.327^{\mathrm{a}} \\
3.64 \pm 0.33^{\mathrm{b}} \\
2.94 \pm 0.18^{\mathrm{b}} \\
3.78 \pm 0.59^{\mathrm{b}}\end{array}$ & $\begin{array}{l}1.74 \pm 0.15 \\
1.00 \pm 0.16^{a} \\
1.50 \pm 0.21^{b} \\
0.94 \pm 0.10^{b} \\
1.20 \pm 0.19^{b}\end{array}$ & $\begin{array}{r}7.10 \pm 0.74 \\
42.00 \pm 2.23^{a} \\
32.60 \pm 1.81^{\mathrm{b}} \\
24.80 \pm 1.48^{\mathrm{b}} \\
25.70 \pm 1.56^{\mathrm{b}}\end{array}$ & $\begin{array}{c}159.00 \pm 1.58 \\
401.60 \pm 2.07^{a} \\
373.00 \pm 10.59^{b} \\
280.20 \pm 3.56^{b} \\
271.00 \pm 4.63^{b}\end{array}$ & $\begin{array}{l}0.92 \pm 0.19 \\
1.24 \pm 0.16^{a} \\
0.78 \pm 0.08^{b} \\
1.18 \pm 0.16^{b} \\
1.12 \pm 0.26^{b}\end{array}$ \\
\hline
\end{tabular}


Histopathological examination of liver sections from group $D$ chicks showed portal infiltration, but there was no mononuclear cell infiltration. Liver section from chicks in group $E$ revealed almost normal architecture. These results are shown in Figure 2.

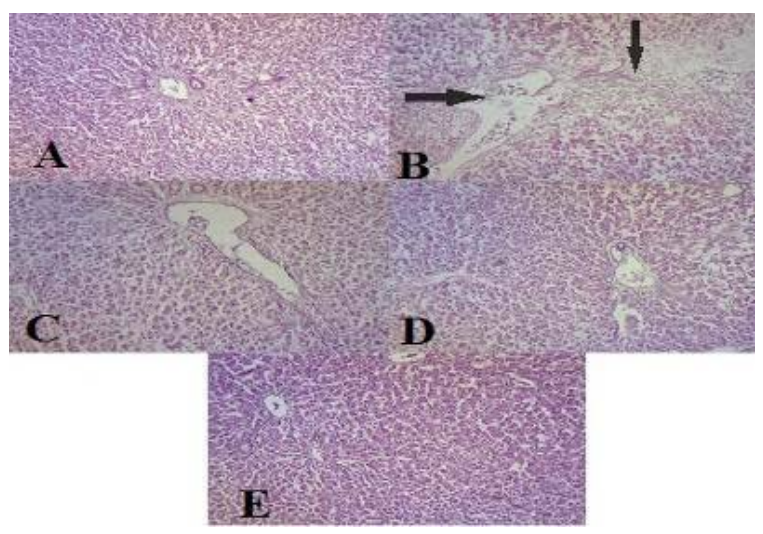

Figure 2: Histological features of liver of chicks (H\&E, $\times 100)$. A: Liver section of control chicks showing normal hepatic cords radiating from the central vein; B: Liver section of chicks in group B showing cellular necrosis (thick arrow) and increased sinusoidal spaces (thin arrow); C: Liver section of group $C$ chicks showing significant recovery of liver parenchyma; D: Liver section of chicks in group $D$ showing near-normal architecture; and E: Liver section of chicks in group $\mathrm{E}$ showing normal architecture

\section{Effect of OTA on histology of bursa of Fabricius}

Histopathological examination of sections of bursa of Fabricius in the control group chicks revealed normal architecture. However, sections of bursa of Fabricius from chicks in group B showed adverse histological changes such as follicular atrophy, epithelial sloughing from some area, and association of epithelium with thin cortical layer. On the other hand, supplementation with $Y S$ significantly reversed the OTA-induced histological alterations. No histopathological changes were observed in sections of bursa of Fabricius from chicks in groups $\mathrm{D}$ and $\mathrm{E}$ (Figure 3 ).

\section{DISCUSSION}

The liver and kidney are vital organs involved in metabolism, detoxication, secretion and excretion of various endogenous and exogenous substances. The kidneys are responsible for the elimination of unmodified drugs and metabolites. Sever liver disease frequently cause alteration in kidney structure and function. Sever abnormalities in liver function causes sodium retention, followed by ascites, linked to profound disturbances of hemodynamics which in turn may disturb renal function.

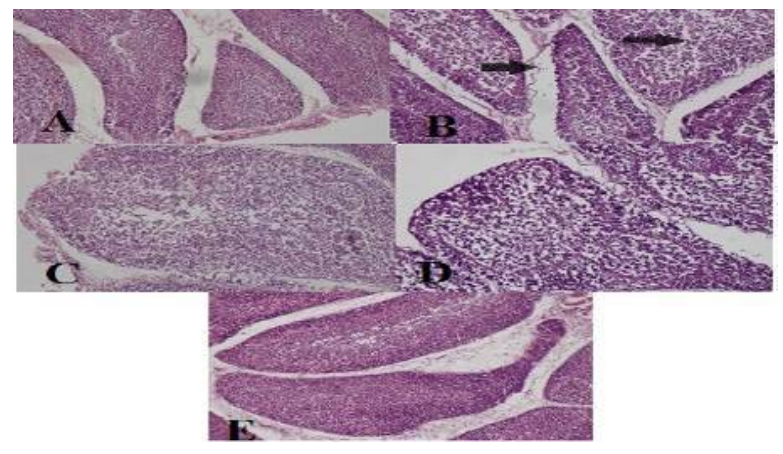

Figure 3: Histological features of bursa of Fabricius of chicks (H\&E, $\times 100)$. A: Section of bursa of Fabricius of control group chicks showing normal bursal follicles; B: section of bursa of Fabricius from group B chicks showing cellular necrosis and sloughing of mucosal membrane; C: section of bursa of Fabricius from group $\mathrm{C}$ showing significant improvement in histological changes induced by OTA; D: section of bursa of Fabricius from group $D$ chicks showing significant improvement in histological changes induced by OTA; and E: section of bursa of Fabricius from group $E$ chicks showing normal architecture

Ochratoxin A (OTA), a fungal secondary metabolite, is a nephrotoxic mycotoxin present in agricultural produce [1]. Glucomannan, which is present in cell wall of yeast is usually added to food products to adsorb mycotoxins. The present study investigated the protective effect of $Y S$ and its components in broiler chicks exposed to OTA.

The observed toxic effects of OTA on indices of liver and kidney functions in this study are in agreement with those reported in previous studies. Similar alterations in serum levels of TP, albumin and creatinine, and changes in activities of ALT and AST were reported in broiler chicks fed with OTA-contaminated diet at doses of 130 $790 \mathrm{ppb}$ or $567 \mathrm{ppb}$ [15], and $0.5-4 \mathrm{mg} / \mathrm{kg}$ bwt feed [10]. It has been suggested that the OTAinduced reduction in serum level of TP may be due partly to decreased albumin level, or pathological alteration in liver synthetic capacity [10]. At a level of $200 \mu \mathrm{g} / \mathrm{kg}$ bwt, OTA significantly reduced serum TP and albumin. It has been reported that supplementation of feed with OTA at doses of 50 and $100 \mathrm{ppb}$ significantly altered the levels and activities of key liver enzymes [16]. Changes in serum proteins levels reflect the state of liver function, and are sensitive indicators of ochratoxicosis. It is likely that OTA is an inhibitor of hepatic protein synthesis.

Increases in the levels of TP and albumin after the addition of $Y S$ have also been reported in 
previous studies $[17,18]$. These results suggest the presence of high quality proteins in YS.

The changes in indices of liver function suggest liver cell damage and increased permeability of plasma membrane. The increased activities of AST and ALT observed in this study are in agreement with results of previous studies [19]. Serum AST and ALT activities are important physiological indices of liver function. Increased activities of AST and ALT reflect impaired amino acid metabolism, a condition that results from liver stress, which in turn leads to liver cell damage and dysfunction.

In this study, the level of creatinine was significantly elevated in chicks fed OTAcontaminated feed, an indication of nephrotoxicity [15]. In a previous study, chicks fed OTA-contaminated feed at levels of 1 to 5 ppm had significant increases in serum levels of uric acid, creatinine, urea and non-protein nitrogen, relative to the control birds [20].

In this study, the OTA-induced vacuolar degeneration observed in the kidneys of chicks is in agreement with the report of Milicevic et al [21]. It has been reported that OTA induces degenerative changes such as swelling, and vacuolar and lipophilic degeneration in tubular epithelial cells. In the present study, histopathological alterations in the kidney were mainly observed in proximal convoluted tubules in the form of cloudy swelling, cytoplasmic degeneration, and pyknosis of proximal convoluted tubule cell nuclei. However, supplementation with YS significantly reversed the OTA-induced histological changes.

Vacuolation of hepatic cells, perivascular mononuclear cell infiltration, bile duct hyperplasia, and swollen and necrotic hepatocytes were the hallmarks of the effect of OTA on the liver. The presence of OTA in the diet of the chicks caused severe degenerative histological changes in the bursa of Fabricius, but YS and YSCM significantly ameliorated the histological alterations induced by OTA. However, the results from histological examination of the bursa of Fabricius of broilers fed diet contaminated with OTA and supplemented with YSCW did not reveal any major histopathological changes. Degenerative alterations such as atrophy and reduction of lymphocytes in lymphoid follicles were the main histological changes in bursa of Fabricius of chicks exposed to OTA [19]. These results suggest that $Y S$ and its components may have ameliorative effect on OTA-induced histological changes in kidney, liver and bursa of Fabricius of rats.

\section{CONCLUSION}

The results obtained in this study indicate that YS and its derivatives improve hepatorenal function and histological changes induced by OTA. However, further investigations are required to determine its effect in humans.

\section{DECLARATIONS}

\section{Acknowledgement}

The authors wish to sincerely thank $\mathrm{Dr}$ Muhammad Ather of $\mathrm{Hi}$ Tech Feeds Pvt Limited for providing the facility used for animal study, and Ms Tasleem Akhter and Dr Saima Masood for helping out with histopathological examination.

\section{Conflict of interest}

No conflict of interest is associated with this work.

\section{Contribution of authors}

This work was done by the authors named in this article, and all liabilities pertaining to claims relating to the content of this article will be borne by them. Ms Huma Mujahid, Dr Abu Saeed Hashmi, Muhammad Zargham Khan, Muhammad Tayyab and Wasim Shehzad conceived and designed the study, and Ms. Huma Mujahid collected and analysed the data, and wrote the manuscript. All the authors proofread and approved the manuscript for publication.

\section{Open Access}

This is an Open Access article that uses a funding model which does not charge readers or their institutions for access and distributed under the terms of the Creative Commons Attribution License (http://creativecommons.org/licenses/by/ 4.0) and the Budapest Open Access Initiative (http://www.budapestopenaccessinitiative.org/rea d), which permit unrestricted use, distribution, and reproduction in any medium, provided the original work is properly credited.

\section{REFERENCES}

1. Vega J, Kocsube S, Peteri Z, Vagvolgyi, Toth $B$. Chemical, physical and biological approaches to prevent 
ochratoxin $A$ induced toxicosis in humans and Animals. Toxins. 2010; 2 (7): 7083 - 7088.

2. Aslam SM, Rivzi AH, Beg AE, Blaszkewicz M, Golka K, Gisela H, Degen. Analysis of Ochratoxin A Blood Levels in Bladder Cancer Cases and Healthy Persons from Pakistan. J Toxicol Environ Health. 2012; 75: 1176 1184.

3. Garcia AR, Avila E, Rosiles R, Petrone VM. Evaluation of two mycotoxin binders to reduce toxicity of broiler diets containing ochratoxin $A$ and T-2 toxin contaminated grain. Avian Dis. 2003; 47 (3): 691 - 699.

4. Krogh P, Hald B, Plestina R, Ceovic S. Balkan (endemic) nephropathy and foodborne ochratoxin A: preliminary results of a survey of foodstuffs. Acta Pathol Microbiol Scand, Sec B. 1977; 85: 238 - 240

5. IARC, International Agency for Research on Cancer. Ochratoxin A: IARC monographs on evaluation of carcinogenic risks to humans. Some naturally occurring substances: Food items and constituents, heterocyclic aromatic amines and mycotoxins 1993; 56: 489 - 521.

6. Amézqueta $S$, Peñas EG, Arbizu MM, Cerain $A L$. Ochratoxin A decontamination: A review. Food Control. 2009; 4 (20): 326 - 333.

7. Hashmi I, Pasha TN, Jabbar MA. Study of adsorption potential of yeast sludge against aflatoxins in broiler chicks. J Anim Plant Sci. 2006; 16: 12 - 14.

8. Khan A, Aalim MM, Khan MZ. Does distillery yeast sludge ameliorate moldy feed toxic effects in White Leghorn hens? Toxin Rev. 2017; 2017: 1278707.

9. Valentino MJG, Kalaw SP, Galvez CT, Reyes RG. Mycota of distillery yeast sludge as source of single cell protein. Mycosphere 2015; 6(3): 241-247

10. Zahoor Ul-Hassan, Khan MZ, Khan $A$ and Javed I. Immunological Status of the Progeny of Breeder Hens Kept on Ochratoxin A (OTA)- and Aflatoxin B1 (AFB1)Contaminated Feeds. J Immunotoxicol. 2012; 9 (4): 381 $-391$.

11. Bayman P, Baker JL, Doster MA, Michailidis TJ, Mahoney NE. Ochratoxin production by the Aspergillus ochraceus group and Aspergillus alliaceus. Appl Environ Microbiol. 2002; 68: 2326 - 2329.
12. Northcote $D H$ and Horne RW. The chemical composition and structure of the yeast cell wall. Biochemical. 1952; 51 (2): 232 - 239.

13. Guide for the Care and Use of Laboratory Animals. 8th edition. Washington DC: National Academies Press (US); 2011.Littie RD. Histopathologica techniques and practical histochemistry. Mc Graw- Hill, U.S.A, 1954. Pp. $29-45$.

14. Seidal T, Balaton AJ, Battifora H. Interpretation and quantification of immunostains. Am J Surg Pathol 2001;25:1204-1207.

15. Sakhare PS, Harne $S D$, Kalorey DR, Warke $S R$, Bhandarkar $A G$ and Kurkure NV. Effect of Toxiroak® polyherbal feed supplement during induced aflatoxicosis, ochratoxicosis and combined mycotoxicoses in broilers. Veterinarski Arhiv. 2007; 77 (2): 129 - 146

16. El-Barkouky EM and Abu-Taleb AM. The role of vitamin $C$ in improving the performance of male broiler chickens feed ration contaminated with ochratoxin. Egypt. J Appl Sci. 2008; 23 (2A): 1 - 12.

17. Mujahid H, Hashmi AS, Anjum AA, Tipu Y. Detoxification potential of ochratoxin by yeast sludge and evaluation in broiler chicks. J Anim Plant Sci. 2012; 22: 601 - 604.

18. Khan WA, Khan MZ, Khan A. Pathological effects of aflatoxins and their amelioration by vitamin $E$ in White Leghorn layers. Pak Vet J. 2010; 30: 155 - 162.

19. Elaroussi MA, Mohamed FR, Elgendy MS, El Barkouky EM, Abdou AM, Hatab MH. Ochratoxicosis in broiler chickens: Functional and histological changes in target organs. Int J Poult Sci. 2008; 7 (5): 414 - 422.

20. Stoev $S D$, Djuvinov D, Mirtcheva $T$, Pavlov D, Mantle $P$. Studies on some feed additives giving partial protection against ochratoxin $A$ toxicity in chicks. Toxicol Lett. 2002b; 5 (1-2): 33- 50. 15

21. Milićević $D$, Jurić $V$, Stefanović $S$, Jovanović $M$, Janković S. Survey of slaughtered pigs for occurrence of ochratoxin $A$ and porcine nephropathy in Serbia. Int $J$ Mol Sci. 2008; 9 (11): $2169-2183$. 